\title{
Penguatan Kelembagaan Pengelola Dana Bergulir PNPM Mandiri Perdesaan Di Kecamatan Balongpanggang Kabupaten Gresik
}

\author{
Lianto $^{1}$, Sanggar Kanto ${ }^{2}$, Siti Kholifah ${ }^{3}$ \\ ${ }^{1}$ Magister Sosiologi, Fakultas IImu Sosial dan Politik, Universitas Brawijaya \\ 2.3 Jurusan Sosiologi, Fakultas IImu Sosial dan Politik, Universitas Brawijaya
}

\begin{abstract}
Abstrak
Penguatan kelembagaan merupakan salah satu pilar keberlanjutan program PNPM Mandiri Perdesaan. Penelitian ini bertujuan untuk mengkaji penguatan aspek hukum, penguatan kelembagaan, dan kemandirian lembaga pengelola dana bergulir PNPM Mandiri Perdesaan Kecamatan Balongpanggang. Teknik penentuan informan dalam penelitian kualitatif deskriptif ini adalah purposive sampling yaitu informan yang dianggap memahami kegiatan dana bergulir UPK Kecamatan Balongpanggang. Penguatan aspek hukum dilakukan dengan melengkapi legalitas pendirian BKAD sebagai payung hukum kegiatan dana bergulir. Penguatan kelembagaan dilakukan dengan penyusunan mekanisme pengelolaan dana bergulir, peningkatan kapasitas pengelola kegiatan dan kelompok masyarakat dalam pengelolaan keuangan dan kelembagaan, serta kerjasama dengan pihak ketiga untuk pengembangan usaha kelompok masyarakat. UPK Kecamatan Balongpanggang merupakan lembaga masyarakat yang mandiri, yaitu tidak tergantung dengan dana BLM dari pemerintah, hal ini dilihat dari hasil analisa eksistensi lembaga pengelola dana bergulir dengan Teori AGIL dan analisa kinerja lembaga yang masuk dalam kategori UPK sehat.
\end{abstract}

Kata kunci: penguatan kelembagaan, dana bergulir, kemandirian, kemiskinan.

\section{Abstract}

Capacity building is one of the pillars of the continuity program of PNPM Mandiri Perdesaan. This study aims to examine the strengthening of the legal aspects, capacity building, and independent of the revolving fund management. This descriptive study uses qualitative method by applying technique to selected informants. It uses purposive sampling in which informants are able to understand of the revolving fund management activities in UPK Balongpanggang. Strengthening the legal aspect has been done by the complete legality of the establishment of BKAD in which is known as a legal funding management activities. capacity building has also been done by the preparation of the mechanism of revolving fund management, capacity building activities and community managers in financial management and institutional, as well as cooperation with third parties for the communities development. UPK Balongpanggang is an independent public institution, in which is independent from the BLM government. The results shows the analysis of the existence of funding management institutions by AGIL theory and the analysis of the performance of institutions are the classification of healthy UPK.

Keywords: Capacity building, revolving fund management, independent, and poverty.

\section{PENDAHULUAN}

Penguatan kelembagaan merupakan salah satu pilar keberlanjutan Program PNPM Mandiri Perdesaan, meliputi penguatan kapasitas dan status hukum lembaga pengelola dana bergulir yang dibentuk oleh program pemberdayaan masyarakat[1]. Penguatan kelembagaan masyarakat ini bertujuan agar: (a) lebih efektif dalam melayani sebanyak mungkin warga miskin, (b) penyelenggaraan kegiatannya secara hukum terlindungi dan dana yang dikelolanya aman dan akuntabel, serta (c) berkelanjutan dan berkembang melalui kerjasama dengan kelembagaan pemerintah daerah, swasta dan masyarakat. Penguatan kelembagaan ini

\footnotetext{
Alamat Korespondensi

Lianto

Email : lianto_firlian@yahoo.com

Alamat : Raya Bengawan Solo 34 Randuagung Kebomas Gresik 61121
}

diperlukan guna menghindari resiko gagalnya investasi modal sosial yang telah dicurahkan oleh pemerintah selama ini.

Kecamatan Balongpanggang merupakan salah satu dari empat kecamatan di Kabupaten Gresik yang menerima program pemberdayaan masyarakat PNPM Mandiri Perdesaan sejak awal program tahun 2003 yang mampu menghasilkan aset produktif dana bergulir cukup tinggi sebesar Rp. 7.539.994.237,- dengan jumlah pemanfaat sebanyak 76 kelompok masyarakat. Tetapi disisi lain Kecamatan Balongpanggang pada tahun 2013 masih masuk kategori kecamatan miskin[2]. dengan indikasi masih memperoleh dana BLM sebesar 3 milyar.

Menurut Basrowi (2011), salah satu permasalahan dalam pemberdayaan masyarakat adalah belum memadainya kelembagaan masyarakat yang dapat mengakomodasi kepentingan masyarakat lokal[3]. Sehingga 
kegiatan penguatan kelembagaan masyarakat untuk mewujudkan lembaga pengelola dana bergulir yang mandiri merupakan hal penting yang harus dilakukan dalam proses pemberdayaan. Uphoff (1986), menjelaskan bahwa ada beberapa hal yang dapat mengakibatkan lembaga lokal tidak berkembang, yaitu: (a) resistensi elit lokal, penduduk dan organisasi yang kepentingannya beda, (b) subordinasi pengelolaan lembaga, (c) ketidakefektifan pengelolaan lembaga, dan (d) terjadinya perpecahan internal [4].

Penelitian ini bertujuan untuk mengkaji penguatan aspek hukum bagi eksistensi dan peran lembaga pengelola dana bergulir, mengkaji penguatan kelembagaan atas pengelolaan dana bergulir, dan mengkaji kemandirian lembaga pengelola dana bergulir yang dibentuk oleh PNPM Mandiri Perdesaan di Kecamatan Balongpanggang Kabupaten Gresik. Kemandirian yang dimaksud adalah ketika sudah tidak ada lagi dana stimulan BLM dari pemerintah, apakah lembaga ini masih tetap dapat melaksanakan kegiatan operasionalnya.

\section{METODE PENELITIAN}

Penelitian ini menggunakan pendekatan kualitatif deskriptif, yaitu menggambarkan kondisi lembaga pengelola dana bergulir dengan cara melakukan identifikasi bagaimana penguatan aspek hukum dan kelembagaan lembaga pengelola dana bergulir, menganalisa eksistensi lembaga dengan teori AGIL Talcott Parsons dan analisa kinerja berdasarkan standar PTO PNPM Mandiri Perdesaan, serta menginterpretasikan kemandirian lembaga pengelola dana bergulir tersebut.

Teknik penentuan informan yang digunakan adalah purposive sampling, dimana informan yang dipilih ditentukan terlebih dahulu meliputi: pengelola lembaga, fasilitator, dan kelompok masyarakat pemanfaat dana bergulir. Teknik pengumpulan data yang digunakan adalah studi kepustakaan, focus group discussion, wawancara mendalam, observasi, dan dokumentasi [5].

Teknik analisis data yang digunakan adalah analisis deskriptif yang berupa uraian tentang penguatan kelembagaan lembaga pengelola dana bergulir UPK Kecamatan Balongpanggang. Menurut Miles dan Huberman (1992), analisis data penelitian kualitatif dilakukan dengan tiga alur, yaitu reduksi data, penyajian data, dan penarikan kesimpulan berdasarkan rumusan masalah[6] .

\section{HASIL DAN PEMBAHASAN}

\section{Penguatan Aspek Hukum}

Kegiatan dana bergulir yang diswakelolakan oleh masyarakat kepada Unit Pengelola Kegiatan (UPK) Kecamatan Balongpanggang memiliki keunikan dalam pelaksanaan operasionalnya, yaitu: (a) resiko pinjaman menjadi tanggung jawab bersama (b) kegiatan dilakukan secara kolektif dari, oleh dan untuk masyarakat, (c) SOP dana bergulir disesuaikan kondisi masyarakat, (d) keberpihakan kepada kelompok rumah tangga miskin, dan (e) melibatkan unsur pemerintah sebagai pelindung[7] .

Lembaga pengelola dana bergulir Kecamatan Balongpanggang tidak memerlukan bentuk badan hukum karena bersifat kepemilikan publik, tetapi yang diperlukan adalah payung hukum yang kuat untuk melindungi kegiatan pengelolaan dana bergulir. Keberadaan lembaga ini akan memiliki payung hukum yang kuat manakala proses pendirian Badan Kerjasama Antar Desa (BKAD) Kecamatan Balongpanggang memenuhi regulasi pembentukan BKAD.

Aspek legalitas pendirian BKAD Kecamatan Balongpanggang sampai saat ini hanya dikuatkan dalam AD/ART BKAD yang ditetapkan oleh musyawarah antar desa (MAD). Oleh karena itu perlu adanya penguatan aspek hukum melalui pembentukan Peraturan Daerah, Peraturan Bupati, dan Peraturan Desa tentang Kerjasama Antar Desa. Satker PNPM Kabupaten Gresik dan Fasilitator Kabupaten Gresik dapat mendorong Pemerintah Kabupaten Gresik untuk membentuk peraturan daerah dan peraturan bupati tersebut. Sedangkan pembentukan peraturan desa menjadi ranah fasilitator kecamatan untuk mendampingi pemerintahan desa.

Legalitas BKAD dan UPK Kecamatan Balongpanggang sangat berpengaruh dalam membuka peluang kerjasama dengan pihak ketiga untuk mengembangkan kelompok usaha ekonomi lokal, yaitu melalui penerapan teknologi tepat guna, manajemen pemasaran yang andal, dan dukungan modal usaha yang kuat. Saat ini pengelola dana bergulir mampu memberikan bantuan modal usaha dan pelatihan usaha kepada masyarakat miskin, tetapi belum mampu secara maksimal dalam memasarkan hasil produk kelompok masyarakat pemanfaat dana bergulir.

Aset produktif yang dikelola oleh UPK Kecamatan Balongpanggang merupakan aset milik seluruh masyarakat Kecamatan Balongpanggang, bukan milik pengurus, bukan 
juga milik pemerintah kecamatan atau desa. Dari hasil wawancara dengan anggota kelompok masyarakat, mencerminkan beberapa hal, yaitu: (a) adanya kesadaran membayar angsuran pinjaman, (b) kesadaran bahwa mengangsur pinjaman dapat bermanfaat bagi masyarakat yang lain, dan (c) Adanya harapan kelompok masyarakat untuk memperoleh pinjaman tahun depan.

\section{Penguatan Kelembagaan}

Unit pengelola kegiatan (UPK) Kecamatan Balongpanggang mempunyai peran sebagai inkubator sosial ekonomi yang mampu menggerakan perekonomian masyarakat melalui pengelolaan dana bergulir untuk kegiatan usaha ekonomi produktif (UEP) dan simpan pinjam perempuan (SPP).

Dalam konteks penanggulangan kemiskinan, UPK Kecamatan Balongpanggang dapat memberikan solusi dari dua perspektif (Barientos, 2010), yaitu: (a) kemiskinan dari perspektif resources melalui pemberian akses modal usaha dan peningkatan kapasitas kelompok masyarakat miskin, dan (b) kemiskinan dari perspektif partisipasi sosial dan inklusi dengan meningkatkan partisipasi seluruh lapisan masyarakat termasuk masyarakat miskin dalam pembangunan desa [8] .

Penguatan kelembagaan pengelola dana bergulir di Kecamatan Balongpanggang dilakukan dengan cara: (1) penyusunan mekanisme pengelolaan dana bergulir, (2) penguatan kapasitas pengurus UPK dan kelompok masyarakat dalam pengelolaan keuangan, (3) penguatan UPK dan kelompok masyarakat secara kelembagaan, dan (4) pengembangan jaringan kerjasama dengan pihak lain.

Kegiatan dana bergulir PNPM Mandiri Perdesaan merupakan salah satu kegiatan yang berpihak kepada masyarakat miskin, hal ini dapat dilihat dari beberapa hal, yaitu: (a) Syarat pembentukan kelompok masyarakat adalah sebagian besar melibatkan masyarakat miskin dan penggunaan dana untuk rencana usaha atau pengembangan usaha, (b) Surplus kegiatan dalam satu tahun anggaran sebesar 1 milyar yang dialokasikan kepada masyarakat miskin, yaitu: $15 \%$ dalam bentuk bantuan sosial RTM, 10\% untuk pelatihan kelompok masyarakat, dan $75 \%$ untuk tambahan aset dana bergulir yang pemanfaatnya adalah masyarakat miskin, dan (c) adanya tabungan tanggung renteng yang digunakan untuk membantu masyarakat miskin ketika tidak mampu mengangsur.
Penguatan kapasitas pengurus UPK dalam pengelolaan keuangan diberikan dalam bentuk pelatihan administrasi keuangan dan pendampingan oleh fasilitator kecamatan. Pengelolaan keuangan di UPK Kecamatan Balongpanggang sudah berjalan dengan baik, dokumen dan arsip keuangan juga sudah tertata dengan baik. Pencatatan sudah dilakukan oleh kasir secara langsung saat terjadi transaksi. Bendahara UPK juga sudah tertib dalam melakukan pengecekan transaksi harian dan ketua UPK juga rutin melakukan cek saldo dana. Disiplin dalam pencatatan transaksi dan kesadaran tinggi pengurus UPK dalam melaksanakan tupoksi merupakan modal sosial lembaga untuk menghindari terjadinya penyalahgunaan dana bergulir.

Rapat koordinasi kelembagaan UPK Kecamatan Balongpanggang yang dilaksanakan tiap bulan dengan melibatkan seluruh komponen pengelola dana bergulir merupakan sarana yang cukup efektif untuk meningkatkan kapasitas pengelola. Beberapa karakteristik Rakor kelembagaan yang dilaksanakan oleh UPK Kecamatan Balongpanggang sehingga tercipta tim pengelola dana bergulir yang solid, antara lain:

(1). Rakor kelembagaan sebagai sarana memperoleh informasi terkini.

Setiap informasi yang diperoleh dari hasil pelatihan, bimtek, dan rakor yang diselenggarakan oleh satker kabupaten atau provinsi akan disampaikan dalam rakor kelembagaan, sehingga seluruh pengelola kegiatan dana bergulir Kecamatan Balongpanggang dapat memahami kebijakan terbaru dari pemerintah.

(2). Rakor kelembagaan sebagai sarana evaluasi pelaksanaan kegiatan.

Seluruh pengelola kegiatan dana bergulir berhak mengetahui hasil kegiatan dan permasalahan yang dihadapi oleh lembaga, serta bersama-sama berusaha untuk ikut "urun rembug" mencari solusi terbaik, hal ini dapat menambah kebersamaan dalam mencapai tujuan organisasi.

(3). Rakor kelembagaan sebagai sarana penyampaian ide kreatif.

Ide kreatif untuk pengembangan kegiatan pinjaman dana bergulir di Kecamatan Balongpanggang sering muncul ketika diadakan rakor kelembagaan, misalnya muncul ide "SPP Award" yang diberikan kepada kelompok SPP yang memiliki kinerja terbaik, yaitu penilaian dari aspek keuangan, 
kelembagaan dan output kegiatan. Ide ini dapat mendorong kelompok masyarakat pemanfaat dana bergulir untuk bersaing meningkatkan kinerjanya.

Penguatan kelembagaan kelompok masyarakat Kecamatan Balongpanggang dilakukan dengan cara pendampingan kelompok masyarakat oleh fasilitator kecamatan bersama KPMD, yaitu pendampingan yang dapat mendorong kelompok masyarakat agar mampu menyusun dan memiliki AD/ART sebagai acuan kegiatan mereka. Keberadaan AD/ART kelompok masyarakat sangat penting untuk mencegah terjadinya permasalahan pengunduran diri pengurus, sebab dalam AD/ART nantinya akan diatur masa kerja pengurus kelompok dan mekanisme pengelolaan kegiatan kelompok. Dengan memiliki AD/ART kelompok, ketergantungan terhadap peran tokoh masyarakat sebagai pengurus kelompok akan berkurang, sebab mekanisme reorganisasi sudah diatur di dalam AD/ART kelompok tersebut.

Pengembangan jaringan kerjasama dengan pihak lain merupakan salah satu unsur yang penting untuk pelestarian kegiatan PNPM Mandiri Perdesaan khususnya pelestarian pinjaman dana bergulir. Pengembangan jaringan yang berkaitan dengan pengelolaan dana bergulir mencakup hal-hal yang bersifat: tambahan permodalan, bantuan teknis usaha, kerjasama program dengan berbagai pihak seperti pemerintah, swasta, atau lembaga keuangan.

Agar kelompok masyarakat di Kecamatan Balongpanggang mampu mempunyai daya tarik bagi pihak lain untuk melakukan kerjasama, selain dilakukan penguatan kelompok masyarakat melalui penyusunan AD/ART dan penguatan administrasi keuangan, juga diperlukan penguatan jaringan usaha, jaringan pembiayaan usaha dan jaringan bantuan teknis bagi pengembangan kelompok usaha.

\section{Kemandirian Lembaga Dana Bergulir}

Analisis kemandirian lembaga pengelola dana bergulir PNPM Mandiri Perdesaan Kecamatan Balongpanggang dilakukan dengan dua tahap, yaitu pertama dilakukan analisa terhadap eksistensi lembaga pengelola dana bergulir tersebut dengan menggunakan teori sosiologi AGIL (10) dan yang kedua dilakukan analisa kinerja lembaga pengelola dana bergulir dilihat dari aspek kinerja kuantitatif dan aspek kelembagaan.

\section{Analisis Eksistensi Lembaga Pengelola Dana Bergulir}

[9]Eksistensi lembaga pengelola dana bergulir Kecamatan Balongpanggang sangat dibutuhkan oleh masyarakat terutama rumah tangga miskin di Kecamatan Balongpanggang, karena mereka telah memahami manfaat dari keberadaan lembaga ini. Hal tersebut tidak terlepas dari upaya pengelola lembaga dalam mensosialisasi kan program dan memberikan pelayanan sebaik mungkin kepada masyarakat. Namun kondisi ini akan semakin baik jika didukung oleh aspek legalitas yang memadai sehingga dapat memberikan peluang terhadap pengembangan lembaga dan kelompok masyarakat melalui kerjasama dengan pihak ketiga.

\section{Adaptation}

Salah satu bentuk sosialisasi program yang dilakukan oleh UPK Kecamatan Balongpanggang adalah melalui komunikasi langsung secara informal kepada masyarakat. hal ini diperankan oleh pendamping lapangan ( $P L$ ) sebagai salah satu pelaku PNPM Mandiri Perdesaan di Kecamatan Balongpanggang. Komunikasi langsung secara informal yang dimaksud adalah pendamping lapangan melakukan obrolan santai dengan masyarakat terutama kaum perempuan yang dilakukan di warung-warung, sawah atau tegalan, dan rumah penduduk yang biasanya dipake tempat berkumpul masyarakat setempat.

Menurut Bapak Kasmuin sebagai salah satu tenaga pendamping lapangan:

"obrolan santai di warung justru lebih efektif karena kita dapat mengetahui secara langsung apa yang diinginkan oleh masyarakat dan merupakan kesempatan kita menjelaskan mengenai program yang kita tawarkan".

Pendekatan secara langsung atau jemput bola oleh tenaga pendamping lapangan juga sangat efektif sebagai salah satu cara melakukan pembinaan kepada kelompok masyarakat peminjam, sehingga kesadaran mereka untuk mengangsur pinjaman semakin tinggi.

Kesadaran masyarakat terhadap arti penting keberadaan lembaga UPK bagi peningkatan kesejahteraan semakin tinggi, salah satu bukti adalah tingkat kolektabilitas dana bergulir mencapai 99\%, artinya masyarakat sadar bahwa dana bergulir bukan hanya untuk kepentingan individu tapi merupakan milik masyarakat yang harus digulirkan untuk masyarakat yang lain.

Figur Bapak Kasmuin merupakan aset penting bagi lembaga UPK Kecamatan Balongpanggang. Peran tenaga pendamping lapangan sebagai 
pihak yang berhadapan langsung dengan masyarakat, yang pertama kali mengetahui permasalahan yang dihadapi oleh kelompok masyarakat, dituntut untuk mampu memberikan solusi awal sebelum permasalahan tersebut dibahas pada forum MAD bersama BKAD.

Keberhasilan pengelola dana bergulir UPK Kecamatan Balongpanggang saat ini tidak terlepas dari peran ketua BKAD Bapak Sukadi, sebagai pelaku program PNPM Mandiri Perdesaan yang sudah mengabdikan diri sejak program terbentuk tahun 2003, Bapak Sukadi yang berlatarbelakang keluarga agamis (beristeri seorang ustadzah yang sangat berpengaruh dilingkungan fatayat NU Kecamatan Balongpanggang) merupakan figur yang disegani, tidak hanya oleh pengelola lembaga PNPM Mandiri Perdesaan tetapi hampir seluruh kelompok masyarakat pemanfaat program dan aparatur pemerintah di wilayah Kecamatan Balongpanggang.

Salah satu kunci sukses UPK Kecamatan Balongpanggang adalah eksistensi lembaga UPK yang benar-benar mandiri artinya tidak ada intervensi dari aparatur pemerintah terhadap pelaksanaan kegiatan. Kondisi ini tidak terlepas dari figur Bapak Sukadi sebagai Ketua BKAD yang selalu menjaga hubungan baik dengan seluruh lapisan masyarakat, beliau mengatakan bahwa "Saya tidak segan-segan mendatangi kepala desa atau kepala dusun untuk bersilaturahim walaupun hanya sekedar ngobrol persoalan sehari-hari" pendekatan seperti ini cukup efektif untuk mensosialisasikan program atau untuk mengetahui permasalahan atau harapan yang diinginkan masyarakat.

Strategi Bapak Sukadi dalam memimpin lembaga pengelola dana bergulir, sehingga mampu menjadikan UPK Kecamatan Balongpanggang menjadi salah satu nominasi UPK terbaik di Jawa Timur, yaitu:

(1). Lembaga UPK harus selalu berupaya membaca kondisi masyarakat yang ada dan berupaya untuk memikirkan bagaimana agar keberadaan lembaga UPK mampu memberikan kemanfaatan secara optimal kepada masyarakat;

(2). Selalu menyempatkan diri bersilaturahim dengan kepala dusun untuk mensosialisasikan program kegiatan dan berusaha mendengarkan keinginan masyarakat terhadap lembaga UPK;

(3). Menggunakan strategi jemput bola dengan mengoptimalkan tenaga pendamping lapangan untuk langsung terjun ke masyarakat mensosialisasikan program dan menampung keinginan masyarakat terhadap lembaga UPK;

(4). Berupaya memintarkan anggota atau pengurus lembaga, hal ini sebagai bentuk kesadaran terhadap arti penting aset sumber daya manusia bagi lembaga UPK.

Beberapa keunikan yang dimiliki oleh pengurus lembaga UPK Kecamatan Balongpanggang diatas seperti komitmen, motivasi dan prinsip pengelolaan dana bergulir serta strategi yang dilakukan untuk pelestarian program, memberikan indikasi bahwa lembaga UPK Kecamatan Balongpanggang akan mampu beradaptasi dengan lingkungan masyarakat.

Persepsi kelompok masyarakat terhadap kemampuan UPK Kecamatan Balongpanggang dalam beradaptasi dengan lingkungannya cukup baik, dimana menurut mereka pelayanan UPK Kecamatan Balongpanggang cukup baik yang didukung oleh beberapa hal, yaitu penggunaan pendekatan kekeluargaan, optimalisasi paguyuban kelompok masyarakat, dan optimalisasi peran tenaga pendamping.

Salah satu perubahan sosial yang terjadi di masyarakat adalah tuntutan tingkat persaingan usaha sangat tinggi, dimana untuk mengembangkan usaha kelompok masyarakat dibutuhkan kemampuan alih teknologi tepat guna dalam proses produksi dan strategi pemasaran produk yang efektif, hal ini merupakan tantangan bagi lembaga pengelola dana bergulir dalam melaksanakan fungsi pemberdayaan masyarakat melalui upaya pengembangan usaha kelompok masyarakat.

Salah satu anggota kelompok masyarakat Desa Sekarputih mengatakan bahwa

"kemampuan produksi sapu, hanger dan keset miliknya sebenarnya cukup bagus tetapi masih sulit bersaing dengan produk dari perusahaan besar, bahkan ketika ikut pameran di UKM provinsi, omzet penjualan tidak sebanding dengan biaya dan proses mengikuti pameran"

Kondisi diatas menunjukan bahwa meskipun secara umum lembaga pengelola dana bergulir Kecamatan Balongpanggang mampu beradaptasi dengan lingkungannya, namun untuk melaksanakan fungsi pengembangan usaha kelompok masyarakat, masih diperlukan tambahan tenaga pendamping fasilitator perguliran dan pengembangan usaha. Selama ini fasilitator kecamatan lebih banyak melaksanakan pendampingan pada kegiatan sarana prasarana fisik dan pengelolaan keuangan dana bergulir. 


\section{Goal-Attainment}

Visi Unit Pengelola Kegiatan (UPK) Kecamatan Balongpanggang adalah meningkatkan taraf kehidupan masyarakat menengah ke bawah di Kecamatan Balongpanggang. Visi tersebut diwujudkan dengan dua misi, yaitu: (a) secara aktif dan kreatif memberdayakan masyarakat, dan (b) meningkatkan perekonomian masyarakat melalui kelompok perempuan.

Tujuan pengelolaan dana bergulir Kecamatan Balongpanggang adalah:

(a). Memberikan kemudahan akses permodalan usaha baik kepada masyarakat sebagai pemanfaat maupun kelompok usaha;

(b). Pelestarian dan pengembangan dana bergulir yang sesuai dengan tujuan PNPM Mandiri Perdesaan;

(c). Peningkatan kapasitas pengelola kegiatan dana bergulir ditingkat wilayah Perdesaan;

(d). Menyiapkan kelembagaan UPK dan lembaga pendukung lainnya sebagai pengelola dana bergulir yang mengacu pada tujuan program secara akuntabel, transparan dan berkelanjutan;

(e). Peningkatan pelayanan kepada RTM dalam pemenuhan kebutuhan permodalan usaha melalui kelompok masyarakat pemanfaat.

Efektivitas pelaksanaan tujuan dipengaruhi oleh ketersediaan sumber daya manusia pelaksana kegiatan dan tersedianya modal kerja dalam melaksanakan kegiatan. Kapasitas pengurus UPK Kecamatan Balongpanggang dalam melaksanakan kegiatan untuk mencapai tujuan yang telah ditetapkan cukup memadai. Aset produktif yang dimiliki juga cukup tinggi sebesar Rp. 7.539.994.237,- dan mampu menghasilkan surplus kegiatan setiap tahun hampir 1 milyar, surplus tersebut sebagian dialokasikan untuk bantuan sosial bagi rumah tangga miskin.

Dengan ketersediaan sumber daya manusia yang cukup memadai, ketersediaan aset produktif yang cukup tinggi yang ditunjang oleh kemampuan menghasilkan surplus kegiatan, dan adanya sistem pengelolaan dana bergulir cukup memadai, UPK Kecamatan Balongpanggang mempunyai kemampuan untuk bisa mewujudkan tujuan yaitu mampu melanjutkan dan melestarikan hasil program PNPM Mandiri Perdesaan.

\section{Integration}

Pelaksanaan kegiatan pinjaman dana bergulir Kecamatan Balongpanggang sampai saat ini dapat berjalan dengan baik dan harmonis. Hal ini ditunjang oleh beberapa hal sebagai berikut:
(1). Komitmen pengurus UPK Kecamatan Balongpanggang untuk selalu berusaha memberikan pelayanan terbaik;

(2). Hubungan antara UPK dengan lembaga pendukung seperti BP-UPK, tim verifikasi, tim pendanaan dan tim penanganan masalah berjalan dengan baik;

(3). Terjadi kerjasama yang baik antara BKAD dengan pelaku PNPM Mandiri Perdesaan seperti camat, PJO kecamatan dan fasilitator kecamatan sehingga tumbuh rasa memiliki terhadap lembaga;

(4). Kelompok masyarakat pemanfaat dana bergulir semakin menyadari arti penting manfaat adanya dana perguliran;

(5). Adanya forum paguyuban kelompok masyarakat semakin mempererat hubungan baik antar kelompok masyarakat dan antara pengelola UPK dengan pokmas;

(6). Adanya rapat koordinasi setiap bulan menjadi sarana efektif untuk menjaga keharmonisan hubungan antara UPK dengan lembaga pendukung.

Beberapa prinsip kepemimpinan yang ditanamkan, sehingga tercipta keharmonisan dalam pengelolaan kegiatan dana bergulir, yaitu:

(1). Prinsip "teman adalah aset terbesar dalam hidup", sehingga kita harus selalu berusaha mencari teman sebanyak mungkin dan tidak memutuskan pertemanan;

(2). Prinsip saling menghargai, dalam mengelola kegiatan dana bergulir kita harus saling menghargai, termasuk dengan bawahan. Ide brilian sering muncul dari bawah, sehingga siapapun harus mau mendengarkan pendapat orang lain;

(3). Prinsip serius dalam mengelola lembaga, dengan motivasi pengabdian kepada masyarakat, pengurus UPK harus mengedepankan kepentingan masyarakat;

(4). Prinsip berani menyimpang dari aturan, selama keputusan tersebut untuk kebaikan masyarakat banyak, misalnya keputusan mengoptimalkan fungsi tim penanganan masalah secara preventif.

Keharmonisan pengelolaan dana bergulir Kecamatan Balongpanggang akan tetap terjaga apabila (a) hubungan antar lembaga pengelola dana bergulir terjalin dengan baik, (b) hubungan antara lembaga pengelola dana bergulir dengan aparatur pemerintah dapat terjalin dengan baik tanpa ada intervensi dari aparatur pemerintah terhadap lembaga, dan (c) pengelola lembaga dana bergulir memiliki pemahaman dan konsisten dalam melaksanakan SOP dan PTO. 


\section{Latency}

Untuk memelihara norma-norma yang telah tertanam dalam pengelolaan dana bergulir, disusunlah standar operasional prosedur (SOP) baik SOP UPK maupun SOP dana bergulir sebagai acuan kerja pelayanan, dan adanya tata tertib kantor yang mengikat seluruh pengelola program.

Beberapa norma yang telah ada di UPK Kecamatan Balongpanggang yang harus dipahami dan dilaksanakan oleh seluruh pengelola program dan masyarakat, adalah:

(1). Tidak ada toleransi bagi korupsi, hal ini berlaku kepada semua pengelola program dan kelompok masyarakat. Pemberian sanksi tegas mulai dari pemecatan sampai kepada ranah hukum akan diberikan jika terjadi korupsi, hal ini cukup efektif sehingga sampai saat ini tidak terjadi korupsi;

(2). Malu jika tidak bisa mengangsur, budaya ini tertanam dalam anggota kelompok masyarakat pemanfaat program. Media yang cukup efektif untuk menanamkan budaya malu ini adalah forum paguyuban kelompok masyarakat, dimana selain membahas tentang informasi best practice juga dipakai untuk membahas penyelesaian tunggakan pengembalian pinjaman dana bergulir oleh kelompok masyarakat;

(3). Nilai kekeluargaan dan rasa saling percaya, norma ini memang harus terus dipupuk tanpa mengurangi arti penting administrasi keuangan.

\section{Analisis Kinerja}

\section{A. Aspek Kuantitatif}

Analisis kinerja UPK Kecamatan Balongpanggang dari aspek kuantitatif terdiri dari kinerja keuangan dan kinerja pengelolaan pinjaman. Analisis kinerja keuangan dilakukan dengan menilai sistem pengelolaan keuangan yang mencakup proses perencanaan, pelaporan, dan hasil pengelolaan.

Kinerja keuangan UPK Kecamatan Balongpanggang tergolong baik, hal ini tercermin dari rasio-rasio keuangan yang melebihi standar yang telah ditetapkan dalam Petunjuk Teknis Operasional PNPM Mandiri Perdesaan Penjelasan $X$ tentang Pengelolaan Dana Bergulir, Hasil perhitungan rasio-rasio keuangan tersebut adalah sebagai berikut:
Tabel 1 Hasil Perhitungan Rasio Keuangan UPK Kecamatan Balongpanggang tahun 2014

\begin{tabular}{|c|l|c|c|c|}
\hline No & $\begin{array}{l}\text { Jenis Rasio } \\
\text { Keuangan }\end{array}$ & Persentase & $\begin{array}{c}\text { Standar } \\
\text { PTO }\end{array}$ & Keterangan \\
\hline 1 & $\begin{array}{l}\text { Rasio } \\
\text { Pendapatan }\end{array}$ & $20,15 \%$ & $>30 \%$ & Cukup Baik \\
\hline 2 & Rasio Biaya & $4,25 \%$ & $<30 \%$ & Baik \\
\hline 3 & $\begin{array}{l}\text { Rasio } \\
\text { Laba/Surplus }\end{array}$ & $15,90 \%$ & $>10 \%$ & Baik \\
\hline 4 & $\begin{array}{l}\text { Efektivitas } \\
\text { Pengelolaan } \\
\text { Dana }\end{array}$ & $8,01 \%$ & $<10 \%$ & Baik \\
\hline 5 & $\begin{array}{l}\text { Resiko } \\
\text { Pinjaman }\end{array}$ & $9,04 \%$ & $<25 \%$ & Baik \\
\hline 6 & $\begin{array}{l}\text { Alokasi } \\
\text { Surplus }\end{array}$ & $75,07 \%$ & $>50 \%$ & Baik \\
\hline
\end{tabular}

Sumber : Diolah oleh peneliti

Analisis kinerja pengelolaan pinjaman dilakukan dengan menilai sistem atau aturan perguliran, kondisi permodalan, dan hasil pengelolaan pinjaman. Kinerja pengelolaan pinjaman UPK Kecamatan Balongpanggang tergolong baik, Hasil perhitungan indikator penilaian kinerja pengelolaan pinjaman tersebut adalah sebagai berikut:

Tabel 2 Hasil Perhitungan Pengelolaan Pinjaman UPK Kecamatan Balongpanggang tahun 2014

\begin{tabular}{|c|l|c|c|c|}
\hline No & \multicolumn{1}{|c|}{ Indikator } & $\%$ & $\begin{array}{c}\text { Standar } \\
\text { PTO }\end{array}$ & Ket \\
\hline 1 & $\begin{array}{l}\text { Pertumbuhan } \\
\text { Modal }\end{array}$ & $30,75 \%$ & $>10 \%$ & Baik \\
\hline 2 & $\begin{array}{l}\text { Pertambahan } \\
\text { Jumlah } \\
\text { Kelompok }\end{array}$ & $49,02 \%$ & $>10 \%$ & Baik \\
\hline 3 & $\begin{array}{l}\text { Tingkat } \\
\text { Pengembalian }\end{array}$ & $98,99 \%$ & $>80 \%$ & Baik \\
\hline 4 & $\begin{array}{l}\text { Resiko } \\
\text { Pinjaman }\end{array}$ & $1,01 \%$ & $<20 \%$ & Baik \\
\hline
\end{tabular}

Sumber : Diolah oleh Peneliti

\section{B. Aspek Kelembagaan}

Penilaian kinerja dari aspek kelembagaan dilakukan untuk mengetahui apakah kelembagaan UPK Kecamatan Balongpanggang dan lembaga pendukungnya mempunyai sistem atau aturan yang memadai dalam pengelolaan dan pelestarian program, mempunyai kapasitas SDM yang mendukung, proses yang transparan dan hasil yang akuntabel (11).

Kinerja UPK Kecamatan Balongpanggang dari aspek kelembagaan UPK tergolong baik dan dapat dijelaskan sebagai berikut:

(a). Kapasitas Pengurus, secara umum kapasitas pengurus UPK Kecamatan Balongpanggang berdasarkan beberapa indikator seperti: pemahaman terhadap aturan pengelolaan keuangan dan pengelolaan pinjaman, 
pemahaman tentang tugas dan tanggung jawab, pemahaman tentang pengembangan kelembagaan UPK, pemahaman tentang pengembangan kelompok, dan pemahaman tentang jaringan kelompok adalah cukup baik;

(b). Operasional kerja, UPK Kecamatan Balongpanggang memiliki operasional kerja yang memadai seperti adanya hari kerja yang cukup dalam pelaksanaan tugas, mempunyai rencana kerja yang jelas, mempunyai sistem pengelolaan dokumen yang baik, dan mempunyai media informasi yang memadai;

(c). Aturan pengelolaan keuangan, UPK Kecamatan Balongpanggang dalam melaksanakan tugas dan tanggung jawabnya telah didukung oleh aturan pengelolaan keuangan yang memadai;

(d). Likuiditas UPK Kecamatan Balongpanggang tergolong baik, hal ini tercermin dari kemampuan UPK dalam memenuhi rencana penyaluran pinjaman dan biaya operasional kegiatan selama tiga bulan terakhir;

(e). Aturan perguliran dan penerapannya tergolong sudah baik, hal ini tercermin dari kesesuaian antara aturan-aturan yang mendasari kegiatan UPK dengan prinsipprinsip PNPM Mandiri Perdesaan, UPK telah menerapkan adanya persyaratan kelayakan kelompok pada saat pengajuan proposal, UPK telah menerapkan aturan jasa pinjaman, jangka waktu dan jadwal angsuran, UPK juga telah menerapkan mekanisme verifikasi yang memadai dan transparan serta penerapan prinsip pengelolaan pinjaman yang transparan.

Penilaian kinerja dari aspek lembaga pendukung UPK seperti BP-UPK, tim verifikasi, tim pendanaan, dan penerapan SOP secara umum cukup baik, namun masih perlu perbaikan terutama berkaitan dengan mekanisme kerja yang jelas dan tertulis bagi lembaga pendukung UPK tersebut, hal ini perlu ditunjang dengan penerapan sistem hari kerja yang jelas, penyediaan fasilitas ruang kerja yang memadai dan sistem penggajian secara profesional, agar tugas dan tanggungjawab yang diemban oleh lembaga pendukung UPK tersebut dapat dilaksanakan dengan baik dan profesional serta tidak terkesan sebagai pekerjaan sampingan.

\section{Kemandirian Lembaga Pengelola Dana Bergulir UPK Kecamatan Balongpanggang}

Unit pengelola kegiatan Kecamatan Balongpanggang sebagai lembaga masyarakat yang dibentuk oleh program pemerintah, secara umum termasuk salah satu lembaga masyarakat yang siap untuk mandiri, artinya tidak tergantung dari bantuan pemerintah, sehingga seandainya pada tahun berikutnya sudah tidak ada dana bantuan langsung masyarakat (BLM) yang dikelola oleh PNPM Mandiri Perdesaan, lembaga UPK Kecamatan Balongpanggang akan tetap dapat survive dan siap menjadi lembaga masyarakat yang mampu melaksanakan kegiatan operasionalnya. Hal ini ditunjang oleh beberapa hal sebagai berikut:

(1). Aspek keuangan menunjukan bahwa UPK Kecamatan Balongpanggang termasuk kategori UPK sehat, dengan kemampuan menghasilkan surplus tinggi yaitu sekitar 1 Milyar per tahun akan mampu memenuhi biaya operasional;

(2). Keberadaan lembaga UPK Kecamatan Balongpanggang sangat dirasakan manfaatnya oleh masyarakat yaitu mampu memberikan akses permodalan bagi masyarakat miskin;

(3). Komitmen pengelola program PNPM Mandiri Perdesaan Kecamatan Balongpanggang dalam upaya meningkatkan kemanfaatan lembaga UPK bagi masyarakat miskin sangat tinggi, sehingga kepengurusan pengelolaan dana bergulir menjadi solid, hal ini merupakan modal sosial yang berharga bagi pelestarian lembaga UPK.

\section{KESIMPULAN}

Beberapa kesimpulan yang diperoleh dari hasil penelitian mengenai penguatan kelembagaan lembaga pengelola dana bergulir UPK Kecamatan Balongpanggang, antara lain:

(1). Penguatan aspek hukum bagi eksistensi dan peran lembaga pengelola dana bergulir Kecamatan Balongpanggang dilakukan dengan cara melengkapi legalitas pendirian BKAD sebagai payung hukum penyelenggaraan kegiatan dana bergulir, Payung hukum atau legalitas BKAD sangat berpengaruh dalam membuka peluang agar lembaga ini dapat menjalin kerjasama dengan pihak ketiga;

(2). Penguatan kelembagaan pengelola dana bergulir PNPM Mandiri Perdesaan Kecamatan Balongpanggang dilakukan 
dengan cara penyusunan mekanisme dana bergulir, peningkatan kapasitas pengelolaan keuangan, peningkatan kapasitas secara kelembagaan, dan pengembangan jaringan kerjasama dengan pihak ketiga;

(3). Eksistensi lembaga pengelola dana bergulir UPK Kecamatan Balongpanggang sangat dibutuhkan oleh masyarakat, hal ini dapat dilihat dari (a) kemampuan lembaga dalam beradaptasi dengan lingkungan masyarakat, (b) kemampuan lembaga dalam mewujudkan tujuan yang tercermin pada ketersediaan sumber daya manusia, ketersediaan aset produktif, kemampuan menghasilkan surplus, dan sistem pengelolaan dana bergulir, (c) kemampuan dalam menjaga keharmonisan komponen lembaga pengelola dana bergulir, (d) kemampuan dalam memelihara norma-norma yang ada di dalam lembaga pengelola dana bergulir. Lembaga ini merupakan lembaga masyarakat yang mandiri, artinya jika sudah tidak ada lagi dana stimulan dari pemerintah, lembaga ini akan tetap survive dan mampu melaksanakan kegiatan operasionalnya, hal ini dapat dilihat dari aspek kuantitatif dimana kinerja keuangan dan kinerja pengelolaan pinjaman UPK Kecamatan Balongpanggang tergolong baik, dan dari aspek kelembagaan dimana kinerja kelembagaan UPK dan pendukung UPK tergolong baik, sehingga secara keseluruhan UPK Kecamatan Balongpanggang termasuk kategori UPK sehat.

\section{Saran}

Untuk memperkuat aspek legalitas pendirian Badan Kerjasama Antar Desa (BKAD) Kecamatan Balongpanggang sebagai payung hukum pengelolaan kegiatan dana bergulir, maka diperlukan fasilitasi oleh Satker PNPM Mandiri Perdesaan Kabupaten Gresik dan Tim Fasilitator Kabupaten Gresik untuk mendorong pemerintah Kabupaten Gresik membuat peraturan daerah dan peraturan bupati yang mengatur tentang kerjasama antar desa melalui pemanfaatan Forum Semiloka DPRD Kabupaten Gresik. Perlu adanya fasilitasi oleh tim fasilitator kecamatan bersama penanggung jawab operasional kecamatan yang didukung oleh kader pemberdayaan masyarakat desa (KPMD) untuk mendukung penguatan kapasitas pemerintahan desa dalam menyusun peraturan desa tentang pembentukan badan kerjasama desa, dan Perlu adanya fasilitasi oleh tim fasilitator kecamatan
Balongpanggang dalam penyusunan AD/ART Kelompok masyarakat, sehingga tidak ada ketergantungan antara keberlanjutan kegiatan dengan pengurus kelompok masyarakat, yaitu terutama berkaitan dengan masa kerja pengurus kelompok masyarakat.

\section{UCAPAN TERIMA KASIH}

Terima kasih peneliti sampaikan kepada institusi Universitas Brawijaya yang telah memberikan support kepada peneliti hingga kegiatan penelitian ini dapat diselesaikan. Penelitian ini tidak berarti apa-apa tanpa ada keterlibatan dari masyarakat dimana penelitian ini dilakukan, kepada mereka peneliti mengucapkan terima kasih atas kesediaannya menjadi tempat belajar dalam mengupas kehidupan bermasyarakat.

\section{DAFTAR PUSTAKA}

[1] Kementerian Perencanaan dan Pembangunan Nasional, Bappenas. 2013. Penanggulangan Kemiskinan dalam Sistem Perencanaan Pembangunan Nasional. Rakernas PNPM Pedesaan 18 Juni 2013. Jakarta.

[2] Kementerian Koordinator Bidang Kesejahteraan Rakyat. 2012. Peta Jalan PNPM Mandiri Menuju Keberlanjutan Program Pemberdayaan Masyarakat. Strategi, Pilar Kebijakan, dan Rencana Aksi. Jakarta.

[3] Basrowi. 2011. Pemberdayaan Masyarakat Tertinggal, Laporan Hasil Penelitian. Lampung: Unila.

[4] Uphoff, Norman. 1986. Local Institutional Development. Kumarian Press. Westhartford. Connecticut.

[5] Sugiyono. 2008. Metode Penelitian Kuantitatif, Kualitatif dan R\&D. Bandung: Alfabeta.

[6] Miles, Matthew B. dan Huberman, A. Michael. 1992. Analisis Data Kualitatif. Terjemah oleh Tjetjep Rohandi. UI-Pers. Jakarta.

[7] Kementerian Dalam Negeri Republik Indonesia. 2013. Petunjuk Teknis Operasional Program Nasional Pemberdayaan Masyarakat (PNPM) Mandiri Perdesaan. Direktorat Jenderal Pemberdayaan Masyarakat dan Desa.

[8] Barrientos, Armando. 2010. Social Protection and Poverty, Social Policy and Development Programme Paper Number No 42. E-paper. 
United Nations Research Institute for Social Development.

[9] Ritzer, George. 2012. Teori Sosiologi Modern. Jakarta: Kencana Prenada Media Group.

[10] Soenyono. 2007. Sosiologi Pemberdayaan Masyarakat (Community Empowerment). Surabaya: Jenggala Pustaka Utama.
[11]Eaton, Joseph. 1986. Pembangunan Lembaga dan Pembangunan Nasional. Jakarta: Universitas Indonesia Press. 